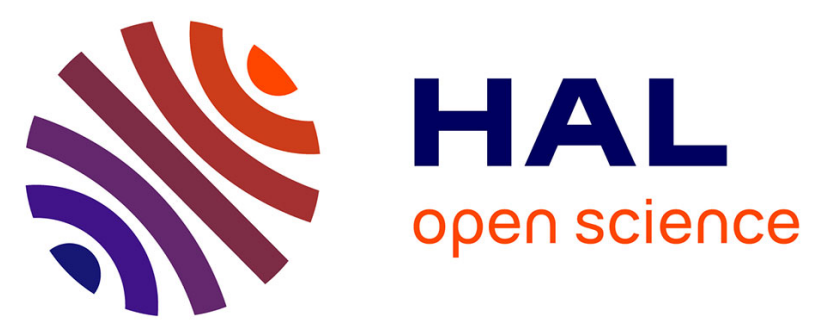

\title{
Dietary Oat Bran Increases Some Proinflammatory Polyunsaturated Fatty-Acid Oxidation Products and Reduces Anti-Inflammatory Products in Apolipoprotein E -/- Mice
}

Jetty Chung-Yung Lee, Dalal Samir Alghawas, Kaisa Poutanen, Kin Sum

Leung, Camille Oger, Jean Marie Galano, Thierry Durand, Hani El-Nezami

\section{To cite this version:}

Jetty Chung-Yung Lee, Dalal Samir Alghawas, Kaisa Poutanen, Kin Sum Leung, Camille Oger, et al.. Dietary Oat Bran Increases Some Proinflammatory Polyunsaturated Fatty-Acid Oxidation Products and Reduces Anti-Inflammatory Products in Apolipoprotein E -/- Mice. Lipids, 2018, 53 (8), pp.785796. 10.1002/lipd.12090 . hal-02613696

\section{HAL Id: hal-02613696 \\ https://hal.umontpellier.fr/hal-02613696}

Submitted on 3 Jun 2021

HAL is a multi-disciplinary open access archive for the deposit and dissemination of scientific research documents, whether they are published or not. The documents may come from teaching and research institutions in France or abroad, or from public or private research centers.
L'archive ouverte pluridisciplinaire HAL, est destinée au dépôt et à la diffusion de documents scientifiques de niveau recherche, publiés ou non, émanant des établissements d'enseignement et de recherche français ou étrangers, des laboratoires publics ou privés. 


\title{
Dietary Oat Bran Increases Some Proinflammatory Polyunsaturated Fatty-Acid Oxidation Products and Reduces Anti-Inflammatory Products in Apolipoprotein $\mathbf{E}^{-/-}$Mice
}

\author{
Jetty Chung-Yung Lee ${ }^{1} \cdot$ Dalal Samir AlGhawas ${ }^{1} \cdot$ Kaisa Poutanen $^{2,3} \cdot$ Kin Sum Leung $^{1} \cdot$ \\ Camille Oger $^{4} \cdot$ Jean-Marie Galano $^{4} \cdot$ Thierry Durand $^{4} \cdot$ Hani El-Nezami ${ }^{1}$
}

\begin{abstract}
Oat bran is suggested to attenuate atherosclerotic conditions by regulating dyslipidemia, endothelial function, and oxidative damage. Through the measurement of oxidized polyunsaturated fatty acid (PUFA), oxidative stress, and inflammation status in liver and heart tissues of apolipoprotein $\mathrm{E}^{-/-}\left(\mathrm{ApoE}^{-/-}\right)$, mice fed with high fat diet (HFD) or HFD with oat bran (HFD + Oat) were investigated. Using liquid chromatography tandem mass spectrometry (LC-MS/MS), PUFA and over 40 types of its oxidized products were assessed. The HFD + Oat group had augmented adrenic acid (ADA), eicosapentaenoic acid (EPA), and docosahexaenoic acid (DHA) and suppressed n-3 docosapentaenoic acid levels in the liver tissues compared to the HFD group. Arachidonic acid (ARA) and $\alpha$-linolenic acid (ALA) levels were elevated and ADA was suppressed in the heart tissues of the HFD + Oat group compared to the HFD group. Furthermore, enzymatically mediated oxidized ARA product levels (9-, 11- and 20-HETE [hydroxyeicosatetraenoic acid], and $\mathrm{PGF}_{2 \alpha}$ ) were
\end{abstract}

Supporting information Additional supporting information may be found online in the Supporting Information section at the end of the article.

Jetty Chung-Yung Lee

jettylee@hku.hk

1 School of Biological Sciences, The University of Hong Kong, Pokfulam Road, Hong Kong SAR

2 Institute of Public Health and Clinical Nutrition, University of Eastern Finland, FI-70029, Finland

3 Food and Health Research Centre, VTT Technical Research Center of Finland, FI-02044, Finland

4 Institut des Biomolécules Max Mousseron, UMR 5247 CNRS, ENSCM, Université de Montpellier, F-34093, France augmented and those of the oxidized DHA products (4-, 7-, 10-, 11-, 13-, and 14-HDHA [hydroxy-docosahexaenoic acid]) were reduced in the liver tissues of the HFD + Oat group. It also increased $17-\mathrm{F}_{2 \mathrm{t}}$-dihomo-isoprostane and 7- $\mathrm{F}_{2 \mathrm{t}}$-dihomo-isofuran derived from nonenzymatic oxidation of ADA in the heart and liver tissues, and those from ALA namely $16-\mathrm{F}_{1 \mathrm{t}}$-phytoprostane and 16(RS)-13-epi$\mathrm{ST} \Delta^{14}$-9-phytofuran. Our study showed oat bran to be a weak antioxidant and lacked anti-inflammatory properties in atherosclerotic mice. Elevation of oxidized PUFA products that are potentially proinflammatory and vasoconstrictors (HETE, $\mathrm{PGF}_{2 \alpha}$ ) with simultaneous reduction of those that are anti-inflammatory (HDHA) may not be desirable in the pathogenesis of atherosclerosis.

Keywords Atherosclerosis - HDHA - HETE .

Isoprostanes · Oat bran · Polyunsaturated fatty acid

Lipids (2018) 53: 785-796.

$\begin{array}{ll}\text { Abbreviations } & \\ \text { ARA } & \text { arachidonic acid } \\ \text { ADA } & \text { adrenic acid } \\ \text { ALA } & \alpha \text {-linolenic acid } \\ \text { ApoE-/- } & \text { Apolipoprotein } \mathrm{E}^{-/-} \\ \text {COX } & \text { cyclooxygenase } \\ \text { CRP } & \text { c-reactive protein } \\ \text { CYP } & \text { cytochrome P450 } \\ \text { EPA } & \text { eicosapentaenoic acid } \\ \text { DHA } & \text { docosahexaenoic acid } \\ \text { DPA } & \text { docosapentaenoic acid } \\ \text { Dihomo-IsoP } & \text { dihomo-isoprostane } \\ \text { eNOS } & \text { endothelial nitric oxide synthase }\end{array}$




\begin{tabular}{|c|c|}
\hline GAPDH & $\begin{array}{l}\text { Glyceraldegyde-3-phospahte } \\
\text { dehydrogenase }\end{array}$ \\
\hline HEK & Human embryonic kidney \\
\hline HETE & hydroxyeicosatetraenoic acid \\
\hline HDHA & hydroxy-docosahexaenoic acid \\
\hline HFD & high fat diet \\
\hline IL1 $\beta$ & Interleukin-1-beta \\
\hline IsoF & isofuran \\
\hline IsoP & isoprostane \\
\hline LC-MS/MS & $\begin{array}{l}\text { liquid chromatography tandem mass } \\
\text { spectrometry }\end{array}$ \\
\hline LNA & linoleic acid \\
\hline LOX & lipoxygenase \\
\hline NADPH & Nicotinamide adenine dinucleotide phosphate \\
\hline NeuroF & neurofuran \\
\hline NeuroP & neuroprostane \\
\hline NFKB & $\begin{array}{l}\text { Nuclear factor kappa-light-chain-enhancer } \\
\text { of activated B cells }\end{array}$ \\
\hline $\mathrm{O}_{2}^{-}$ & superoxide \\
\hline Phox & phagocyte oxidase \\
\hline PhytoP & phytoprostane \\
\hline PFA & paraformaldehyde \\
\hline $\operatorname{PPAR} \alpha$ & $\begin{array}{l}\text { peroxisome proliferator-activated receptor } \\
\text { alpha }\end{array}$ \\
\hline PUFA & polyunsaturated fatty acid \\
\hline RIPA & Radioimmunoprecipitation assay buffer \\
\hline ROS & reactive oxygen species \\
\hline RT & room temperature \\
\hline $\mathrm{SMC}$ & smooth muscle cell \\
\hline SPE & solid phase extraction \\
\hline $\mathrm{TNF} \alpha$ & Tumor necrosis factor alpha \\
\hline VED & vascular endothelial dysfunction \\
\hline VCAM & vascular cellular adhesion molecule \\
\hline
\end{tabular}

\section{Introduction}

Progression of atherosclerosis is complex that involves multiple components including vascular endothelial dysfunction (VED), oxidative stress, inflammation, and dyslipidemia such as elevated blood triacylglycerols. Due to the high fiber content, oat is widely recommended in the diet to prevent atherosclerosis. However, oat also contains a considerable amount of polyunsaturated fatty acids (PUFA) (Gornas et al., 2016) that are essential to human lipid function. PUFA are prone to enzymatic or nonenzymatic oxidation by the prevailing in vivo reactive oxygen species (ROS) and release oxidized PUFA products that have functional roles to human health (Galano et al., 2017).

ROS is one cause of VED (Sacerdoti et al., 2015) that contributes to hypertension and atherosclerosis development (Griendling et al., 2000). In vitro studies indicate that ROS such as superoxide $\left(\mathrm{O}_{2}{ }^{\bullet-}\right)$ from nicotinamide adenine dinucleotide phosphate (NADPH) oxidases is linked to vascular smooth muscle cell (SMC) growth (Zafari et al., 1998) and elevated NADPH oxidase-phagocyte oxidase (phox) expression is associated with hypertension and atherosclerosis (Weber et al., 2005).

The action of nonenzymatic oxidation via free radical/ ROS on $n-6$ PUFA leads to the release of $\mathrm{F}_{2}$-isoprostanes $\left(\mathrm{F}_{2}\right.$-IsoP) and $\mathrm{F}_{2}$-dihomo-isoprostanes $\left(\mathrm{F}_{2}\right.$-dihomo-IsoP) from arachidonic acid (ARA) and adrenic acid (ADA), respectively. Products of $n$-3 PUFA include phytoprostanes (PhytoP) from $\alpha$-linolenic acid (ALA), neuroprostanes (NeuroP) from docosahexaenoic acid (DHA), $\mathrm{F}_{3}$-isoprostanes $\left(\mathrm{F}_{3}\right.$-IsoP) from eicosapentaenoic acid (EPA), and $\mathrm{F}_{3}$-Iso$\mathrm{P}_{\mathrm{DPA} n-3}$ from docosapentaenoic acid (DPAn-3) (Demion et al., 2017; Galano et al., 2017; Joumard-Cubizolles et al., 2017). Under extreme oxidative stress and/or high oxygen tension $(>21 \%)$, the furanoid form of these oxidized PUFA products is generated (Cuyamendous et al., 2016).

Insofar, it is known that oxidized products of $n-6$ PUFA are toxic and those of $n-3$ PUFA are potentially bioactive (Galano et al., 2017; Roy et al., 2017b). Elevation of IsoP in human is related to inflammation and cardiovascular diseases. It also exerts vasoconstriction (Cracowski and Durand, 2006), platelet activation (Greaves et al., 2003), and monocyte adhesion (Kumar et al., 2005) properties, induce proliferation of endothelial and smooth muscle cells (Yura et al., 1999), and enhance vascular reperfusion damage after myocardial infarction (Greaves et al., 2003). Nonetheless, dihomo-IsoP are recognized to be biomarkers for early diagnosis of Rett Syndrome and epilepsy (De Felice et al., 2011; Medina et al., 2015), while NeuroP are noted to protect heart ischemic reperfusion, show antiarrhythmic properties, and to be a viable predictor of atherosclerosis risk (Gladine et al., 2014; Roy et al., 2015, 2017a).

PUFA are also substrates for enzymatic oxidation via cyclooxygenases (COX), lipoxygenases (LOX), or cytochrome (CYP) monooxygenases (Hwang, 2000; Zeldin, 2001). COX-mediated metabolites of ARA (Smith et al., 1996) are viewed to be proinflammatory in coronary thrombosis and chemotaxis responses, whereas LOX-mediated metabolites of ARA are known to have proinflammatory properties related to vascular permeability and vasoconstriction (Hwang, 2000). Furthermore, CYP catalyze the NADPH-dependent oxidation (Zeldin, 2001) and release metabolites of ARA that are related to calcium channel signaling in hypertension (Oliw and Sprecher, 1991). In contrast, LOX metabolites of DHA including neuroprotectin D1 and the precursor hydroxydocosahexaenoic acid (HDHA) have anti-inflammatory properties in vascular disease models (Serhan et al., 2008).

In this study, it is postulated that oat bran rich in PUFA takes part in attenuating atherosclerotic conditions by regulating oxidative stress and inflammation by the oxidized PUFA products released. 


\section{Materials and Methods}

\section{Animal Feeding}

Standard diet (AIN-93G Research Diet Inc., New Brunswick, NJ, USA) was fed to apolipoprotein $\mathrm{E}^{-/-}\left(\mathrm{ApoE}^{-/-}\right)$ female mice (Jackson Laboratory, Bar Harbor, ME, USA) for the first 4 weeks of weaning to ensure normal development. Thereafter, the mice were fed with high fat diet (HFD, $n=10$ ) or HFD with oat bran (HFD + Oat, $n=10$ ) for 16 weeks. The HFD constituting of solid milk fat (20\%) and corn oil (1\%) of the diet (Table 1) were added in the feed to accelerate atherosclerosis development. The oat bran added to the HFD was provided by the VTT Technical Research Center of Finland.

The mice were kept in ventilated cages at $23-24{ }^{\circ} \mathrm{C}$ and $60-70 \%$ relative humidity on a $12-$ h day/night cycle. Water

Table 1 The diet composition of high fat diet (HFD) and HFD + oat provided to the experimental apolipoprotein $\mathrm{E}^{-/-}\left(\right.$ApoE $\left.^{-/-}\right)$mice

\begin{tabular}{|c|c|c|}
\hline & HFD & $\mathrm{HFD}+\mathrm{Oat}$ \\
\hline Diet & D12079B & D13011703 \\
\hline Product & $\mathrm{g}$ & $\mathrm{g}$ \\
\hline Protein & 174.3 & 210.4 \\
\hline Carbohydrate & 491 & 577.0 \\
\hline Fat & 212.2 & 229.4 \\
\hline Cholesterol & 2.1 & 1.9 \\
\hline Fiber & 50 & 51 \\
\hline Ingredients & $\mathrm{g}$ & $\mathrm{g}$ \\
\hline Oat bran (containing $\beta$-Glucan) & $0(0)$ & $800(51)$ \\
\hline Cellulose & 50 & 50 \\
\hline Casein 30 mesh & 195 & 195 \\
\hline L-Cysteine & 0 & 0 \\
\hline L-Tryptophan & 0.3 & 0.5 \\
\hline DL-Methionine & 3 & 3 \\
\hline Corn starch & 50 & 0 \\
\hline Maltodextrin 10 & 100 & 100 \\
\hline Sucrose & 341 & 341 \\
\hline Mill fat (Butter) anhydrous & 200 & 200 \\
\hline Corn oil & 10 & 10 \\
\hline Soybean oil & 0 & 0 \\
\hline Mineral mix S10001 & 35 & 35 \\
\hline Mineral mix S10022G & 0 & 0 \\
\hline Calcium carbonate & 4 & 4 \\
\hline Vitamin mix V1001 & 10 & 10 \\
\hline Vitamin mix V10037 & 0 & 0 \\
\hline Choline bitartrate & 2 & 2 \\
\hline Cholesterol & 1.5 & 1.5 \\
\hline t-Butylhydroquinone & 0 & 0 \\
\hline Ethoxyquin & 0.04 & 0.04 \\
\hline
\end{tabular}

and the diet were given ad libitum and sacrificed in a nonfasted state. From weeks 4 to 20, the bodyweight gain was recorded weekly. The experimentations were approved by Department of Health, Hong Kong and the Committee on the Use of Live Animals in Teaching and Research (CULATR no. 2932-13), The University of Hong Kong.

\section{Blood Cholesterol and Triacylglycerols}

Blood samples were taken at inferior vena cava before (4 weeks old) and after (20 weeks old) feeding periods in EDTA tubes, centrifuged at $1000 \times g$ for 5 min for plasma separation, and then stored at $-80{ }^{\circ} \mathrm{C}$. Assay kits were used to determine total cholesterol and triacylglycerol levels in the plasma (Cayman Chemical, Ann Arbor, MI, USA).

\section{Atherosclerotic Plaque Size}

The mice aortic tree was immediately perfused with $4 \%$ paraformaldehyde (PFA) after sacrifice. One set $(n=10)$ was incubated overnight in PFA, then transferred into distilled water and stored at $4{ }^{\circ} \mathrm{C}$. Afterward, it was stained with Sudan IV dye and analyzed using the ImageJ software (USA) to quantify the surface area of the total aortic tree and total plaque lesions.

Another set $(n=10)$ of PFA perfused aortic trees was fixed at $-20{ }^{\circ} \mathrm{C}$. Dissections of $10 \mu \mathrm{m}$ were made at -17 ${ }^{\circ} \mathrm{C}$ using a cryostat. The slides were dried and stained with Oil Red $\mathrm{O}$ and then visualized under a light microscope with a photo attachment (Nikon 80i, Japan). The sections were analyzed to calculate the percentage of the plaque area (stained red) using the ImageJ software.

\section{P22 $^{\text {phox }}$ Determination of the Aortic Root}

A set of slides $(n=10)$ prepared above was immunostained for $\mathrm{p} 22^{\text {phox }}$ expression. They were rehydrated in wash buffer for $10 \mathrm{~min}$ and then incubated in blocking buffer (10\% horse serum, Life Technologies, Carlsbad, CA, USA) for $30 \mathrm{~min}$ at room temperature (RT). The sections were then incubated overnight in a diluted primary antibody p22 phox $(1: 200)$ (Santa Cruz, Dallas, TX, USA) at $4{ }^{\circ} \mathrm{C}$. In brief, for immunodetection, the biotinylated antirabbit antibody (Vector Laboratory Inc. Burlingame, CA, USA) was added to each section and incubated in RT, then fluorescent Alexa Fluor 488 dye (Thermo Fisher Scientific, Waltham, MA, USA) was added and incubated at RT. The counterstain DAPI (4',6-diamidino-2-phenylindole, Life Technologies, USA) was added and incubated in RT. The sections were washed and semidried before placing in an antifade/ mounting medium (Life Technologies, Carlsbad, CA, USA). The slides were visualized using the Zeiss LSM 710 Confocal Microscope (Darmstadt, Germany). The 
argon laser was set at $488 \mathrm{~nm}$ to excite the Alexa Fluor fluorochromes and the pinhole of 1 airy unit was used. The fluorescent intensity was measured using the ZEN software (Zeiss, Darmstadt, Germany).

\section{Vascular Endothelial Function}

The whole aortic tree tissues were homogenized in $100 \mu \mathrm{L}$ radioimmunoprecipitation assay buffer (RIPA) buffer (Sigma-Aldrich, St. Louis, MO, USA) with $0.01 \%$ protease inhibitor cocktail (Sigma-Aldrich, St. Louis, MO, USA) and centrifuged at $16,000 \times g$ for $5 \mathrm{~min}$. The protein concentration was determined using the DC Protein Assay (Bio-Rad, Hercules, CA, USA) and bovine serum albumin (SigmaAldrich, St. Louis, MO, USA) was used as the standard.

Equal concentrations of protein were subjected to electrophoresis on $10 \%$ acrylamide/bis gels (Bio-Rad, Hercules, CA, USA). The proteins were then transferred onto a nitrocellulose membrane (Amersham Biosciences, Freiburg, Germany). The following antibodies were used for detection; vascular cell adhesion molecule-1 (VCAM-1, 1:1000), endothelial nitric oxide synthase (eNOS, 1:1000) (Cell Signaling Technology, Danvers, MA, USA), and C-reactive protein (CRP, 1:2000) (Abcam, Eugene, CA, USA). Glyceraldehyde-3-phospahte dehydrogenase (GAPDH, 1:1000) (Cell Signaling Technology, Danvers, MA, USA) was used as the loading control. The proteins were detected with goat antimouse (1:5000) or goat antirabbit (1:5000) (Abcam, Eugene, CA, USA) peroxidase-linked secondary antibodies. For visualization, the western ECL substrate (BioRad, Hercules, CA, USA) was added, and the blots were quantified using the ChemiDoc XRS+ imaging system and software (Bio-Rad, Hercules, CA, USA).

\section{Lipid Extraction}

Lipid portion of the liver and heart tissues was extracted using the following Folch method (Folch et al., 1957) with modification. In brief, $0.5 \mathrm{mg}$ was homogenized (T25 UltraTurrax, Germany) in ice-cold Folch solution with $0.01 \%$ (w/v) BHT at 24,000 rpm. Aqueous $0.9 \% \mathrm{NaCl}$ was added, mixed, and then centrifuged at $3000 \times g$ for 10 min at $4{ }^{\circ} \mathrm{C}$. The organic phase was dried and hydrolyzed for solid phase extraction (SPE). The mixed-mode, anionic exchange, reversed-phase, SPE cartridges (60 mg MAX Oasis, Waters, Milford, MA, USA) were washed with methanol and conditioned with $20 \mathrm{mM}$ formic acid ( $\mathrm{pH}$ 4.6). The sample was loaded and then washed with $2 \%$ ammonium hydroxide followed by methanol: $20 \mathrm{mM}$ formic acid ( $\mathrm{pH} 4.6$ ) mix (40:60 v/v). Thereafter, the PUFA and its oxidized products were finally eluted with hexane followed by hexane/ethanol/ acetic acid (70:29.5/0.05 v/v). The collected samples were completely dried under nitrogen gas and reconstituted in methanol with a mix of internal standards (Table S1, Supporting information) prepared in methanol, then enclosed with nitrogen gas to prevent any degradation and immediately analyzed using liquid chromatography tandem mass spectrometry (LC-MS/MS).

\section{Lipid Analysis using LC-MS/MS}

Concentration of PUFA and its oxidized products was determined using the LC-MS/MS consisting of a MS/MS 3200 QTRAP system (Sciex, Framingham, MA, USA) and a 1290 Infinity LC system (Agilent, Santa Clara, CA, USA) with a C18 column $(2.6 \mu \mathrm{m}$ particle size, $150 \times 2.1 \mathrm{~mm}$, Phenomenex, Torrance, CA, USA). The analytes were detected by MS/MS using multiple reaction monitoring according to (Lai et al., 2017) and Table S1. MS/MS was set at electrospray ionization mode, the source temperature was $500{ }^{\circ} \mathrm{C}$, and the capillary temperature was $250{ }^{\circ} \mathrm{C}$. ARA, ADA, ALA, DPAn-3, EPA, and DHA and its oxidized products namely prostaglandins, hydroxyeicosatetraenoic acids (5-, 8-, 9-, 11-, 12-, 15-, and 20-HETE), hydroxy-DHA (4-, 7-, 8-, 10-, 11-, 13-, 14-, 16-, 17-, and 20-HDHA), neuroprotectin D1, prostaglandin $\mathrm{F}_{2 \alpha}$, isoprostanoids (IsoP, dihomoIsoP, NeuroP, and PhytoP), and isofuranoids (IsoF, dihomoIsoF, PhytoF, and NeuroF) were quantified by relating their chromatographic peak areas to their corresponding heavylabeled internal standard peak area. The percentage of SPE recovery of all internal standards ranged from $83 \%$ to $104 \%$ and the $\%$ RSD were below $10 \%$. The intraday precision of the analysis ranged from $95 \%$ to $102 \%$ and the RSD was below $10 \%$. Analytes without a corresponding heavy-labeled isotope were quantified using the one with the closest chemical structure. Details of $m / z$ of each analyte and the internal standard used are described in Table S1 and the typical mass spectra of a standard compound are found in Fig. S1. Of note, 33 out of 42 types of oxidized PUFA products measured were detected in the tissues using the LC-MS/MS method. Only those observed are noted in the results.

\section{Statistics}

All data are evaluated using GraphPad Prism (Version 6.01, San Diego, CA, USA). Values are expressed as mean \pm SD. Student's unpaired $t$-test was performed where $p<0.05$ was considered significant.

\section{Results}

\section{Feed Intake, Bodyweight Gain, and Plasma Analysis}

The amount of feed intake by the mice and the rate of bodyweight gain did not differ between HFD and 

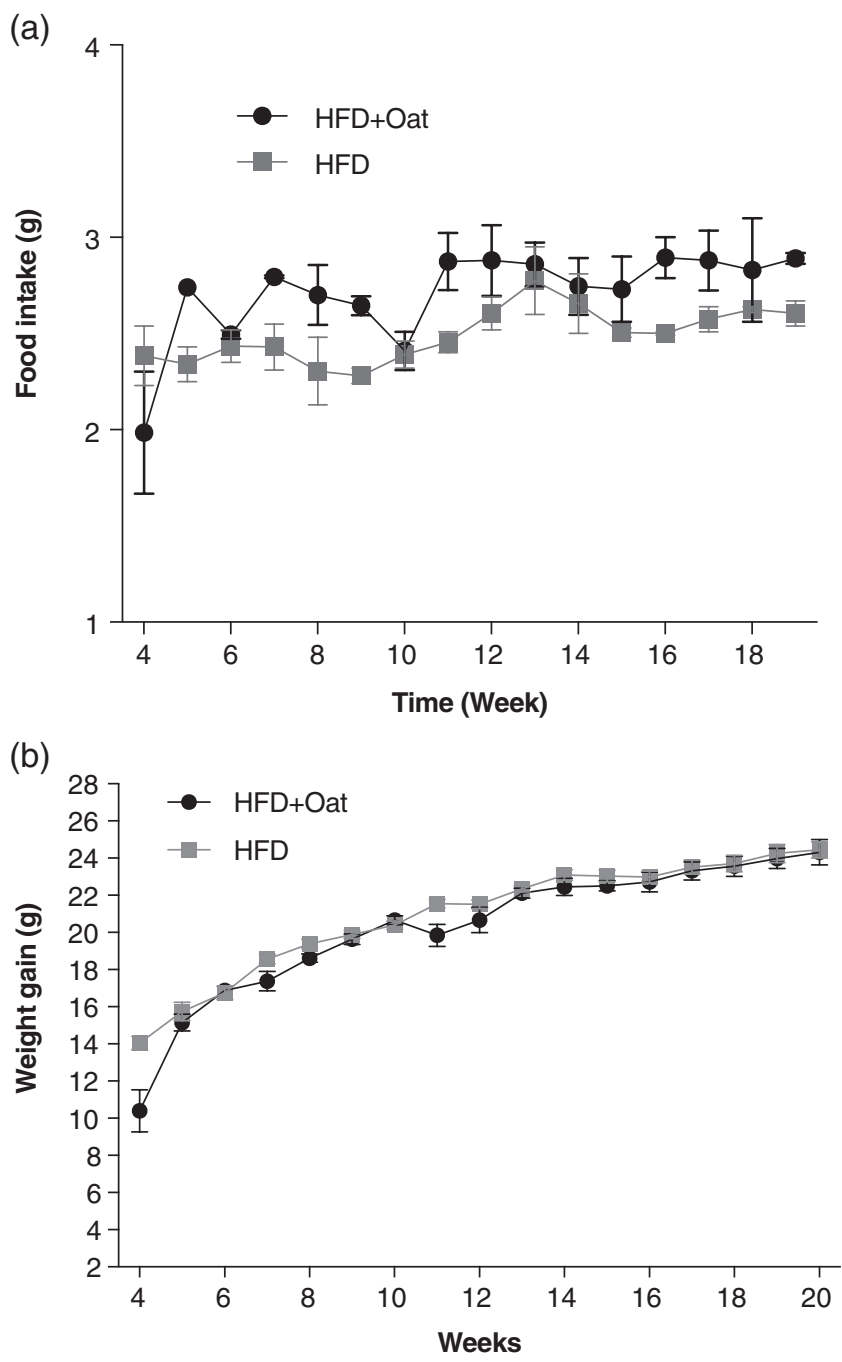

Fig. 1 Average daily food intake (a) and bodyweight gained (b) by the apolipoprotein $\mathrm{E}^{-/-}\left(\mathrm{ApoE}^{-/-}\right)$mice over 16 weeks period fed with high fat diet (HFD) and HFD with oat bran (HFD + oat). Values are mean $\pm \mathrm{SD}(n=10)$

HFD + Oat groups during the feeding period (Fig. 1). Plasma total cholesterol and triacylglycerol levels were significantly elevated after the feeding period, and the levels were similar between HFD and HFD + Oat groups (Table 2).

Table 2 Plasma total cholesterol and triacylglycerol levels after 16 weeks of oat diet

\begin{tabular}{llcc}
\hline Diet & \multicolumn{1}{c}{ HFD } & HFD + Oat \\
\hline Total cholesterol & Before & $3.81 \pm 1.35$ & $2.70 \pm 0.71$ \\
$(\mathrm{mM})$ & After & $6.32 \pm 1.08^{* * *}$ & $6.69 \pm 0.86^{* * *}$ \\
Triacylglycerol & Before & $125.80 \pm 32.10$ & $161.46 \pm 44.07$ \\
$(\mathrm{mg} / \mathrm{dL})$ & After & $271.67 \pm 55.63^{* * * *}$ & $263.58 \pm 44.43^{* * *}$ \\
\hline
\end{tabular}

Values are mean $\pm \mathrm{SD}(n=10)$.

*** $p<0.0001$ before versus after.

\section{Plaque Area and Vascular Endothelial Function of the Aortic Tree and Root}

The plaque area of the aortic root, aortic root including endothelial lining, and aortic tree were significantly reduced in the HFD + Oat group compared to the HFD group (Fig. 2). Also, the HFD + Oat group displayed a trend of $\mathrm{p} 22^{p h o x}$ upregulation $(p<0.06)$ in the aortic root compared to the HFD group. Endothelial functions as measured by CRP, VCAM-1, and eNOS levels were not reduced by HFD + Oat (Fig. 2).

\section{PUFA and its Oxidized Products}

The addition of oat to the HFD altered the PUFA metabolism where ADA, EPA, and DHA were significantly elevated and DPAn-3 suppressed in the liver tissues compared to HFD diet. Levels of ARA and ALA were not altered. In the heart tissues, ARA and ALA were significantly elevated and ADA was suppressed in the HFD + Oat group compared to the HFD group (Fig. 3) while no changes were observed in EPA, DPAn-3, and DHA levels.

Compared to the HFD group, the HFD + Oat group significantly modified oxidized ARA products released through enzymatic oxidation in the tissues (Table 3). Liver and heart tissue levels of 9-HETE, 20-HETE, and PGF $_{2 \alpha}$ were augmented in the HFD + Oat group compared to the HFD group, and 5-HETE, 8-HETE, and 15-HETE levels were suppressed in the liver tissues. There was no significant change in levels of 12- HETE between HFD + Oat and HFD groups in liver and heart tissues, and 5-, 8-, 11-, and 15-HETE levels in the heart tissues.

Levels of oxidized DHA products namely 11- and 14-HDHA were significantly lower in the liver and heart tissues of the HFD + Oat group compared to the HFD group while 4-, 7-, 10-, and 13-HDHA, and NPD1 were lower in the liver tissues and 4-, 10-, and 17-HDHA were higher in the heart tissues. No change was found between HFD and HFD + Oat groups in liver and heart tissues for 8-HDHA levels, and 17-HDHA levels in the liver tissues and 7-HDHA, 13-HDHA, and NPD1 levels in the heart tissues (Table 3 ).

Concentrations of the oxidized PUFA products mediated nonenzymatically were also different in the HFD + Oat group compared to the HFD group (Table 4). The novel oxidative stress biomarker $15-\mathrm{F}_{2 \mathrm{t}}$-IsoP derived from ARA was augmented in the heart tissues of the HFD + Oat group compared to the HFD group. There was no significant change in $15-\mathrm{F}_{2 \mathrm{t}}$-IsoP levels in the liver tissues and $5-\mathrm{F}_{2 \mathrm{t}}$-IsoP levels in both liver and hearth tissues. Levels of $17-\mathrm{F}_{2 \mathrm{t}}$-dihomo-IsoP and $7-\mathrm{F}_{2 \mathrm{t}}$-dihomo-IsoF derived from $\mathrm{ADA}$ of the HFD + Oat group were 
(a)
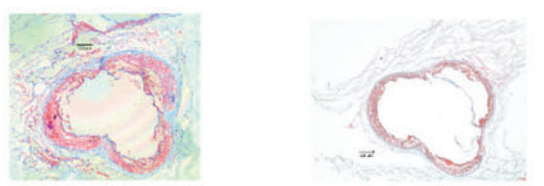

(b)
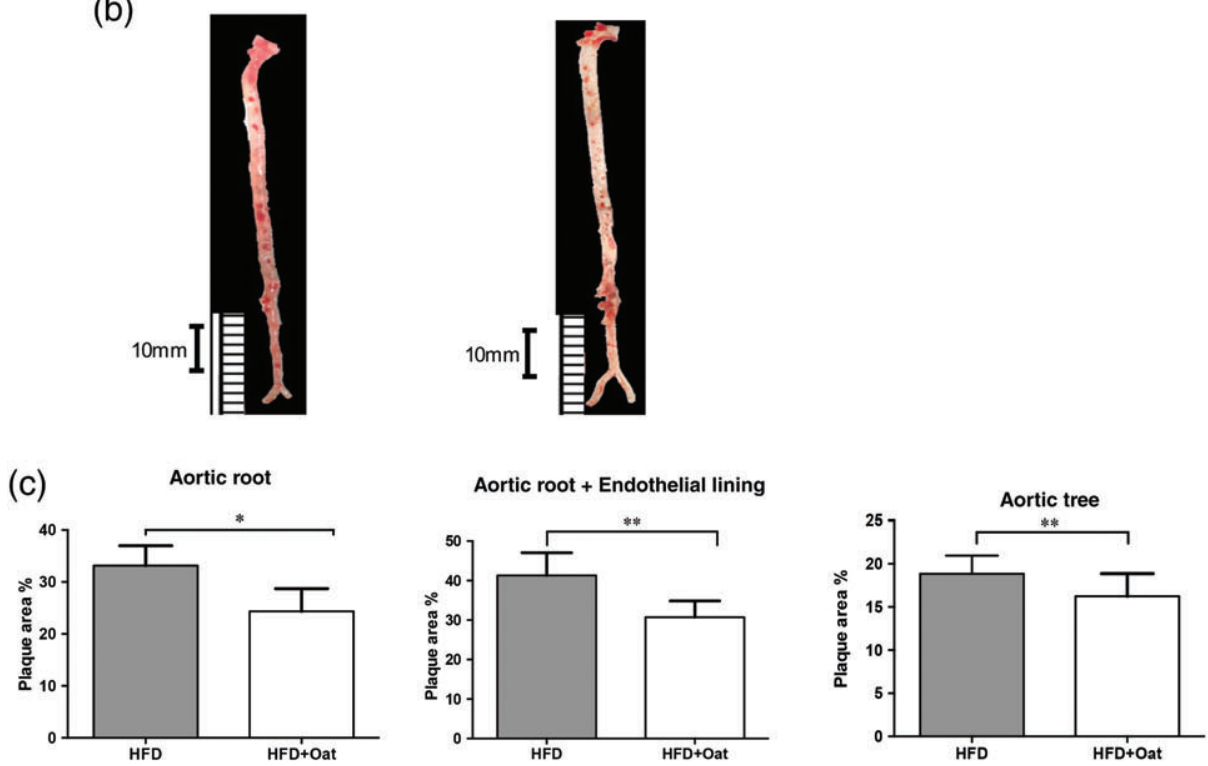

(d) p22 $2^{\text {phox }}$ Fluorescent intensity in acrtic root

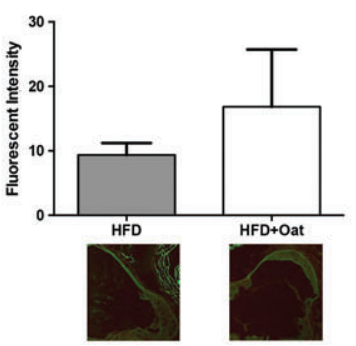

(e)

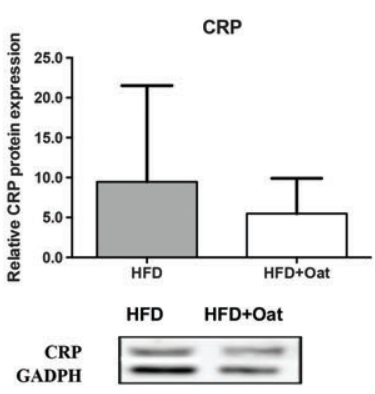

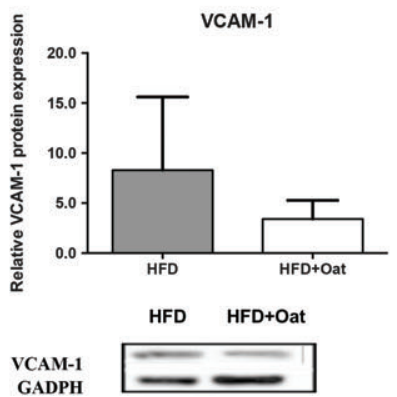

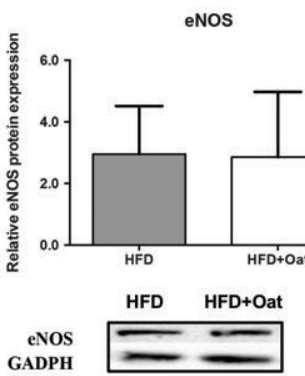

Fig. 2 The effects of dietary intake (16 weeks) on the plaque area in the aortic tree and root of apolipoprotein $\mathrm{E}^{-/-}$(ApoE ${ }^{-/-}$) mice. (a) Whole aortic root stained with oil red O dye. Magnification 20X with measuring scale bar of $200 \mu \mathrm{m}$; (b) Whole aortic tree stained with Sudan IV dye for plaque area. Measuring scale represented as $10 \mathrm{~mm}$; (c) plaque area measured in (b); (d) p22 $2^{\text {phox }}$ expression in the aortic root smooth muscle cells; (e) endothelial function markers expressed normalized to glyceraldegyde-3-phospahte dehydrogenase (GAPDH). Values expressed as mean $\pm \mathrm{SD}$ for $(\mathrm{a}-\mathrm{e})(n=10)$. Significance annotated are $* p<0.05, * * p<0.01$ and $* * * p<0.0001$

elevated significantly in heart and liver tissues compared to the HFD group.

Concentrations of ent-16- $\mathrm{F}_{1 \mathrm{t}}$-PhytoP and $16(R S)$-13-epiST- $\Delta^{14}-9-$ PhytoF derived from ALA were significantly elevated in both liver and heart tissues of the HFD + Oat group compared to the HFD group. Moreover, $9-\mathrm{F}_{1}-\mathrm{PhytoP}$ levels decreased and 16-epi-16- $\mathrm{B}_{1}$-PhytoP increased in the liver tissues but $\mathrm{F}_{1}$-PhytoP levels increased and 16-epi$16-\mathrm{B}_{1}-\mathrm{PhytoP}$ decreased in the heart tissues of the Oat +HFD group compared to the HFD group. 9- $\mathrm{D}_{1}$-PhytoP and 9- $\mathrm{L}_{1}-$ PhytoP levels were unaffected by HFD + Oat diet compared to HFD (Table 4),

Levels of 20-HDHA derived from DHA oxidation were significantly elevated only in the liver tissues of the HFD + Oat group compared to the HFD group while $4-(R S)-4-\mathrm{F}_{4 \mathrm{t}}-\mathrm{NeuroP}$, neurofuran (NeuroF), and 4(RS)-ST$\Delta^{5}$-8-NeuroF were significantly reduced in the heart tissues (Table 4).

16-HDHA and $10-\mathrm{F}_{4 \mathrm{t}}$-NeuroP levels were not altered in the liver and heart tissues of the HFD + Oat group compared 

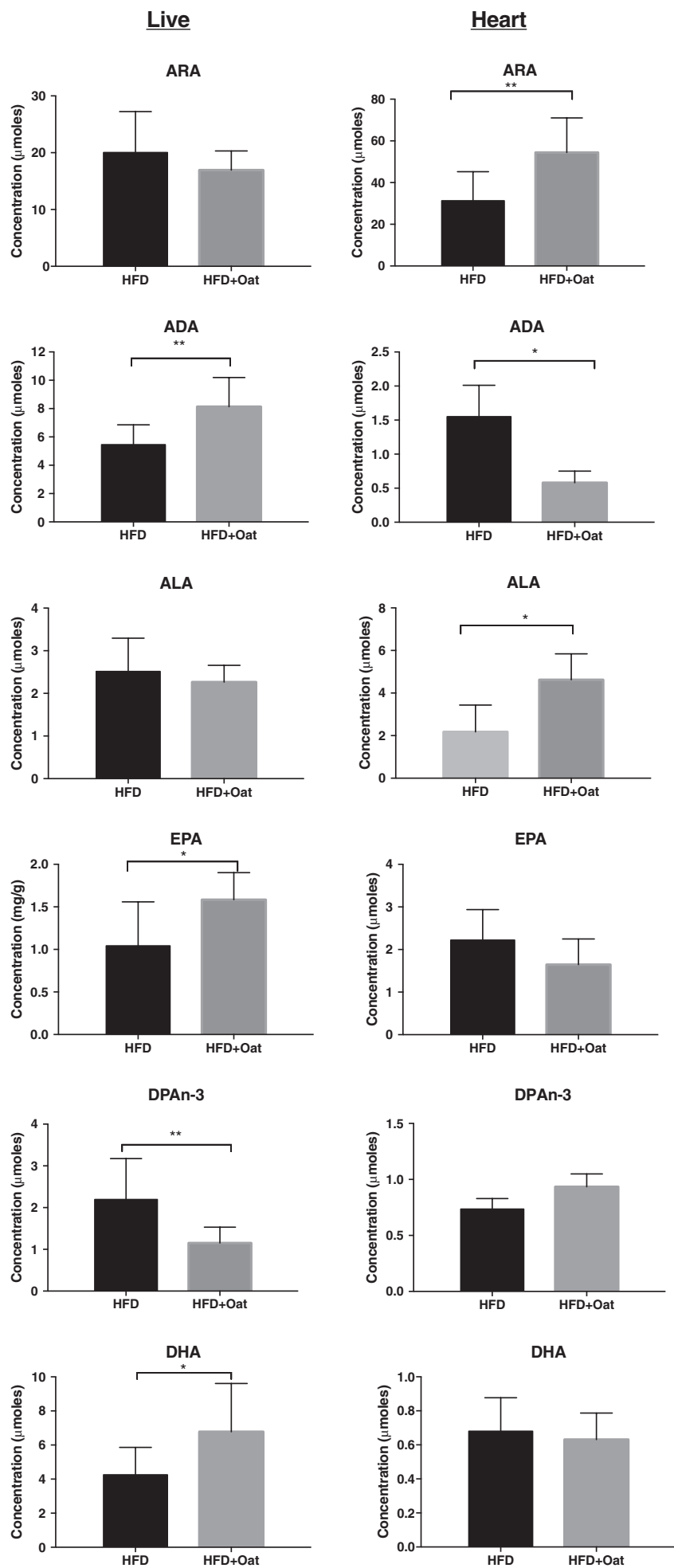

Fig. 3 Concentration of polyunsaturated fatty acids (PUFA) in liver $(n=10)$ and heart $(n=5)$ tissues of apolipoprotein $\mathrm{E}^{-/-}\left(\mathrm{ApoE}^{-/-}\right)$ mice after 16 weeks of diet given. Values are expressed as $\mu$ moles per gram wet weight and column bars are mean \pm SD. Significance annotated are $* p<0.05$ and $* * p<0.01$. ARA, arachidonic acid; ADA, adrenic acid; ALA, $\alpha$-linolenic acid; EPA, eicosapentaenoic acid; $n$-3 DPAn-3, $n-3$ type docosapentaenoic acid; DHA, docosahexaenoic acid

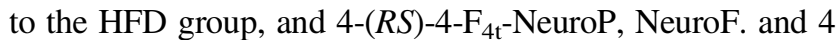
$(R S)$-ST- $\Delta^{5}-8$-NeuroF levels in the liver tissues.

\section{Discussion}

Oat bran is claimed to have antiatherogenic properties by attenuating oxidative stress and inflammation. It is suggested to be a rich source of antioxidants (phytic acid, tocopherols, polyphenolic compounds, flavonoids, and polymeric lignins) and PUFA mainly $n$-6 PUFA, linoleic acid (LNA), n-3 PUFA, and ALA (Andersson and Hellstrand, 2012; Gornas et al., 2016). However, due to the skipped diene double bonds in the structure of PUFA, it is prone to oxidation in in vivo under oxidative stress (Galano et al., 2017). The resulting oxidized products such as those derived from $n-6$ PUFA induced and those from $n$ - 3 PUFA reduced inflammatory cytokines (Serhan et al., 2015) and CRP (Vollmer-Conna et al., 2015). Isoprostanes (IsoP) particularly $5-\mathrm{F}_{2 \mathrm{t}}$-IsoP and $15-\mathrm{F}_{2 \mathrm{t}}$-IsoP released by nonenzymatic oxidation of ARA are known to be valuable biomarkers of oxidative stress, where an increase is associated with numerous diseases (Galano et al., 2017). Interestingly, the levels were not alleviated in the HFD + Oat group compared to HFD indicating that the mice were potentially under continuous oxidative stress throughout the experimental period, in particular the heart. Notwithstanding, triggering $15-\mathrm{F}_{2 \mathrm{t}}-\mathrm{IsoP}$, as shown in the heart tissue of the Oat+HFD group, could affect endothelial functions and cause vasoconstriction. Elevated $15-\mathrm{F}_{2 \mathrm{t}}$-IsoP is suggested to be associated with vascular diseases such as stroke and hypertension diseases (Galano et al., 2017).

Indeed, this study is the first to assess the regulation of PUFA and its oxidized products by oat bran in the liver and heart tissues of atherosclerotic mice. It was shown previously that $A p o E^{-/-}$mice bred with fat- 1 transgenic mice (characterized by hypercholesterolemia and high $n$-3 PUFA tissue levels) had reduced $n-6 / n-3$ PUFA ratios, reduced plaque lesion area size, and reduced proinflammatory, chemoattractants, and adhesion molecules in three sites, the aorta, monocytes, and plasma (Wan et al., 2010) indicating the importance of PUFA balance particularly the lowering of $n-6$ PUFA for healthy heart condition. Our findings showed a change in $n-6 / n-3$ PUFA ratios where it was dominantly altered by $n-3$ PUFA in the liver and $n-6$ PUFA in the heart with HFD + Oat diet. This was not anticipated considering LNA the precursor of ARA is much more abundant than ALA, the precursor of DHA in oat bran (Gornas et al., 2016). Oat bran consumption with HFD changed the dynamics of the PUFA metabolism where in the liver, both ALA and LNA converted to DHA and ARA, respectively, in vivo significantly, and perhaps the ARA 
Table 3 The effect of oat diet in liver and heart tissue: Enzymatic oxidized metabolites of polyunsaturated fatty acids released through the action of cyclooxygenase (COX), lipoxygenase (LOX) or cytochrome P450 (CYP) detected by liquid chromatography tandem mass spectrometry (LCMS/MS)

\begin{tabular}{|c|c|c|c|c|}
\hline & \multirow{2}{*}{$\begin{array}{l}\text { Liver } \\
\text { HFD }\end{array}$} & \multirow[b]{2}{*}{ HFD + Oat } & \multicolumn{2}{|c|}{ Heart } \\
\hline & & & HFD & HFD + Oat \\
\hline \multicolumn{5}{|l|}{ Arachidonic acid } \\
\hline $\begin{array}{c}\text { COX-mediated } \\
\mathrm{PGF}_{2 \alpha}\end{array}$ & $0.59 \pm 0.11$ & $2.31 \pm 0.23 * * *$ & $0.81 \pm 0.12^{\dagger}$ & $1.51 \pm 0.28^{\dagger, * * *}$ \\
\hline \multicolumn{5}{|l|}{ LOX-mediated } \\
\hline 12-HETE & $48.98 \pm 12.23$ & $47.57 \pm 9.37$ & $26.88 \pm 3.66$ & $50.43 \pm 5.88 * * *$ \\
\hline 15-HETE & $1.08 \pm 0.32$ & $0.74 \pm 0.19^{*}$ & $1.55 \pm 0.28$ & $1.77 \pm 0.26$ \\
\hline \multicolumn{5}{|l|}{ CYP-mediated } \\
\hline 8-HETE & $4.66 \pm 1.42$ & $2.68 \pm 1.27 * * *$ & $0.70 \pm 0.19$ & $0.80 \pm 0.18$ \\
\hline 9-HETE & $0.42 \pm 0.03$ & $2.94 \pm 0.52 * * *$ & $0.40 \pm 0.01$ & $1.36 \pm 0.27 * * *$ \\
\hline 11-HETE & $14.71 \pm 2.77$ & $31.18 \pm 5.65^{* * *}$ & $24.79 \pm 4.18$ & $31.16 \pm 5.18$ \\
\hline 20-HETE & $1.22 \pm 0.21$ & $2.88 \pm 0.40 * * *$ & $1.84 \pm 0.34$ & $3.03 \pm 0.72 * *$ \\
\hline \multicolumn{5}{|c|}{ Docosahexaenoic acid } \\
\hline $\begin{array}{c}\text { COX-mediated } \\
\text { 13-HDHA }\end{array}$ & $48.46 \pm 15.09$ & $24.70 \pm 9.40 \hat{*} * * *$ & $0.11 \pm 0.03$ & $0.08 \pm 0.03$ \\
\hline $\begin{array}{l}\text { LOX-mediated } \\
\text { 4-HDHA }\end{array}$ & $265.86 \pm 117.57$ & $19.22 \pm 9.06^{* *}$ & $28.37 \pm 6.13$ & $57.00 \pm 6.20 * * *$ \\
\hline 7-HDHA & $48.12 \pm 14.82$ & $114.27 \pm 68.79^{\wedge} * * *$ & $0.08 \pm 0.01$ & $0.08 \pm 0.02$ \\
\hline 8-HDHA & $1.92 \pm 0.38$ & $2.24 \pm 0.65$ & $3.65 \pm 1.13$ & $3.10 \pm 0.74$ \\
\hline 10-HDHA & $2.31 \pm 0.53$ & $0.35 \pm 0.10 * * *$ & $4.71 \pm 0.49$ & $14.84 \pm 2.13 * * *$ \\
\hline 11-HDHA & $0.12 \pm 0.02$ & $0.05 \pm 0.01 * * *$ & $0.17 \pm 0.02^{\dagger}$ & $0.08 \pm 0.01^{\dagger, * * *}$ \\
\hline 14-HDHA & $0.38 \pm 0.05$ & $0.22 \pm 0.08 * *$ & $0.07 \pm 0.02^{\dagger}$ & $0.03 \pm 0.01^{\dagger, * * *}$ \\
\hline 17-HDHA & $1.81 \pm 0.43$ & $1.50 \pm 0.41$ & $0.43 \pm 0.10^{\dagger}$ & $2.73 \pm 0.37^{\dagger, * * *}$ \\
\hline NPD1 & $0.34 \pm 0.07$ & Trace*** & $0.19 \pm 0.14$ & $0.16 \pm 0.04$ \\
\hline
\end{tabular}

Concentrations of the metabolites are expressed as $\mu \mathrm{g} / \mathrm{g}$ except those annotated ${ }^{\dagger}$ are $\mathrm{ng} / \mathrm{g}$ tissue wet weight or ${ }^{\wedge}$ are pg/g tissue wet weight. Values are mean $\pm \mathrm{SD}, n=10$ for liver and $n=5$ for heart tissues. Trace indicates levels $>1 \mathrm{pg} / \mathrm{g}$ tissue wet weight. HFD, high fat diet; PGF $2 \alpha$, prostaglandin $_{2 \alpha}$; HETE, hydroxyeicosatetraenoic acid; HDHA, hydroxy-docosahexaenoic acid.

$* p<0.05$ versus HFD.

$* * p<0.01$ versus HFD.

$* * * p<0.0001$ versus HFD.

formed rapidly elongated to ADA as well as transported to the heart. This suggests a competition of $\Delta^{6}$ desaturase and $\Delta^{5}$ desaturase enzymes, shared in the PUFA metabolism existed for the conversion and uptake of ARA and DHA (Burdge and Calder, 2005; Goyens et al., 2006).

Nonetheless, our assessment was not performed directly on the aortic plaque and it appears that fatty-acid regulation is more complex in $A p o E^{-/-}$mice when under oxidative stress and inflammation for example cigarette smoke where other fatty-acid lipid species such as sterol lipids, sphingolipids, and glycerophospholipids that were not considered in this study were modified in the atherosclerotic plaque (Sasso et al., 2016). Nevertheless, the uptake of PUFA may also be attributed to the limited 8-HETE level in the liver of the HFD + Oat group. 8-HETE is able to upregulate peroxisome proliferator-activated receptor alpha (PPAR $\alpha$ ) and promote uptake, utilization, and metabolism of fatty acids in rats (Forman et al., 1997).

The role of PUFA in the heart tissue that is the myocardium, is vital for energy, where approximately $60-70 \%$ of the energy is derived from mitochondrial oxidation of fatty acids to allow normal heart contraction to take place (Van der Vusse et al., 2000). Of the oxidized PUFA products, $\mathrm{F}_{4}$-NeuroP from DHA are the most promising bioactive molecules mediated by free radical/ROS oxidation. In particular, 4- $\mathrm{F}_{4 \mathrm{t}}$-NeuroP displayed antiarrhythmic effects in cellulo and in vivo, and protected ischemia-reperfusion injury in mice during myocardial infarction (Roy et al., $2015,2017 \mathrm{a})$. In addition, $4-\mathrm{F}_{4 \mathrm{t}}-\mathrm{NeuroP}$ is proposed to reduce atherosclerosis risk (Gladine et al., 2014) and products formed from nonenzymatic oxidation of DHA to have anti-inflammatory effects (Sethi et al., 1996). Addition of 
Table 4 The effect of oat diet in liver and heart tissue: Nonenzymatic oxidized metabolites of polyunsaturated fatty acids are released through the action of free radical/reactive oxygen species (ROS)

\begin{tabular}{|c|c|c|c|c|}
\hline & \multirow{2}{*}{$\frac{\text { Liver }}{\text { HFD }}$} & \multirow[b]{2}{*}{ HFD + Oat } & \multicolumn{2}{|c|}{ Heart } \\
\hline & & & HFD & $\mathrm{HFD}+$ Oat \\
\hline \multicolumn{5}{|l|}{ Arachidonic acid } \\
\hline $5-\mathrm{F}_{2 \mathrm{t}}-\mathrm{IsoP}$ & $0.45 \pm 0.13$ & $0.41 \pm 0.12$ & $0.03 \pm 0.01$ & $0.03 \pm 0.01$ \\
\hline $15-\mathrm{F}_{2 \mathrm{t}}$-IsoP & $0.30 \pm 0.11$ & $0.34 \pm 0.16$ & $0.38 \pm 0.16$ & $0.90 \pm 0.19 * *$ \\
\hline \multicolumn{5}{|l|}{ Adrenic acid } \\
\hline 17-F Ft -Dihomo-IsoP & $10.58 \pm 3.11$ & $26.77 \pm 13.49 * * *$ & $11.78 \pm 1.01^{\dagger}$ & $29.89 \pm 3.22^{\dagger, * * * *}$ \\
\hline 7-F $\mathrm{F}_{2 \mathrm{t}}$-Dihomo-IsoF & $2.36 \pm 0.53$ & $8.52 \pm 4.44 * * *$ & $0.19 \pm 0.130$ & $0.68 \pm 0.21^{* *}$ \\
\hline \multicolumn{5}{|l|}{$\alpha$-Linolenic acid } \\
\hline 9-D - -PhytoP & $0.47 \pm 0.07$ & $0.37 \pm 0.06^{* *}$ & $0.50 \pm 0.08$ & $0.43 \pm 0.15$ \\
\hline 9-F - -PhytoP & $1.21 \pm 0.21$ & $0.46 \pm 0.10^{* * *}$ & $0.02 \pm 0.01$ & $0.03 \pm 0.01 *$ \\
\hline 9- $\mathrm{L}_{1}$-PhytoP & $0.14 \pm 0.09$ & $0.22 \pm 0.08$ & $0.54 \pm 0.13$ & $0.45 \pm 0.11$ \\
\hline 16-epi-16-B -PhytoP $^{-}$ & $0.18 \pm 0.09$ & $0.44 \pm 0.08 * * *$ & $0.95 \pm 0.11$ & $0.69 \pm 0.18^{*}$ \\
\hline Ent-16- $\mathrm{F}_{1 \mathrm{t}}-\mathrm{PhytoP}$ & $0.18 \pm 0.03$ & $0.64 \pm 0.10^{* * *}$ & $0.17 \pm 0.03$ & $0.48 \pm 0.12 * * *$ \\
\hline $16(R S)$-13-epi-ST $\Delta^{14}$-9-PhytoF & $0.20 \pm 0.04$ & $0.60 \pm 0.10^{* * *}$ & $0.45 \pm 0.12$ & $1.47 \pm 0.28 * * *$ \\
\hline \multicolumn{5}{|l|}{ Docosahexaenoic acid } \\
\hline 16-HDHA & $0.15 \pm 0.03$ & $0.16 \pm 0.03$ & $0.27 \pm 0.08$ & $0.35 \pm 0.10$ \\
\hline 20-HDHA & $0.44 \pm 0.15$ & $0.12 \pm 0.04 * * *$ & $0.32 \pm 0.13$ & $0.29 \pm 0.06$ \\
\hline $4(R S)-4-\mathrm{F}_{4 \mathrm{t}}-$ NeuroP & $0.19 \pm 0.04$ & $0.23 \pm 0.06$ & $1.06 \pm 0.23$ & $0.74 \pm 0.16^{*}$ \\
\hline $10-\mathrm{F}_{4 \mathrm{t}}-\mathrm{NeuroP}$ & Trace & Trace & Trace & Trace \\
\hline NeuroF & $11.03 \pm 3.80$ & $12.60 \pm 2.94$ & $8.93 \pm 1.10$ & $3.61 \pm 0.64 * * *$ \\
\hline $4(R S)-\mathrm{ST}-\Delta^{5}-8-\mathrm{NeuroF}$ & $7.44 \pm 1.48$ & $6.98 \pm 1.62$ & $5.55 \pm 1.08$ & $1.71 \pm 0.22 * * *$ \\
\hline
\end{tabular}

Concentrations of the metabolites are expressed as $\mu \mathrm{g} / \mathrm{g}$ except those annotated ${ }^{\dagger}$ are $\mathrm{ng} / \mathrm{g}$ tissue wet weight. Values are mean $\pm \mathrm{SD}, n=10$ for liver and $n=5$ for heart tissues. Trace indicates levels $>1 \mathrm{pg} / \mathrm{g}$ tissue wet weight. HFD, high fat diet; IsoP, isoprostane; NeuroP, neuroprostane; NeuroF, neurofuran; HDHA, hydroxy-docosahexaenoic acid.

$* p<0.05$ versus HFD.

$* * p<0.01$ versus HFD.

$* * * p<0.0001$ versus HFD.

oat bran to HFD in atherosclerotic mice diet in fact reduced $4-\mathrm{F}_{4 \mathrm{t}}-\mathrm{NeuroP}$ in the heart tissues and this observation complements with the elevated $15-\mathrm{F}_{2 \mathrm{t}}$-IsoP. The increase of $15-\mathrm{F}_{2 \mathrm{t}}$-IsoP lowered vascular activity that is enhanced vasoconstriction and simultaneously disrupted heart muscle function through the reduced $4-\mathrm{F}_{4 \mathrm{t}}-\mathrm{NeuroP}$ release in the HFD + Oat group. In addition, the supply of oxygen appeared to be limited in the heart tissues as shown by the decrease in NeuroF, which is released when the oxygen tension is above $21 \%$ ( above $760 \mathrm{mmHg}$ ). Insofar, NeuroF has been associated with oxidative injury in the cerebral cortex (Solberg et al., 2012) and little is known for its role in the heart function. Even though further evaluations are required, oat bran does not appear to benefit vascular function in atherosclerotic condition.

Although the addition of oat to HFD enhanced DHA levels in the liver, it dysregulated products mediated by enzymatic oxidation. Notably, 14-HDHA was suppressed in the liver and heart tissues but 17-HDHA was upregulated in the heart tissues. These are known mediators that take part in the release of proresolving biomarkers like maresins, resolvins, and protectins to "resolve" inflammation by reducing cytokines such as tumor necrosis factor alpha (TNF $\alpha$ ), interleukin-1-beta (IL1 $\beta$ ), and nuclear factor kappa-light-chain-enhancer of activated B cells (NFkB) (Serhan et al., 2008, 2015). In spite of this, 4-HDHA that is proposed to be antiangiogenic (Sapieha et al., 2011) was upregulated in the heart tissue but not liver tissues in the HFD + Oat group compared to the HFD group. Furthermore, 15-HETE derived from enzymatic ARA oxidation, which is suggested to be a vasoconstrictor and eliminate inflammatory response, was also inhibited in the liver tissues of the HFD + Oat group compared to the HFD group. Instead, our study showed 11-HETE to be induced in liver tissues of the HFD + Oat group, which in part may be a symptomatic response for atherosclerosis ( $\mathrm{Zu}$ et al., 2016). Notwithstanding, 20-HETE was elevated in the liver and heart tissues of the Oat+HFD group, which further disputes the benefit of oat bran in atherosclerosis. 20-HETE is a proinflammatory 
biomarker and a potent vasoconstrictor where an increase is associated with several vascular diseases such as hypertension, cerebrovascular diseases, and coronary heart disease (Jamieson et al., 2017).

There has been strong evidence to show that dietary and circulating ALA can reduce the risk of coronary vascular disease (Pan et al., 2012). Nonenzymatic oxidation of ALA results in the release of PhytoP (Jahn et al., 2008) that exhibits potent anti-inflammatory properties in human embryonic kidney (HEK) cells and RAW 264.7 macrophages, and apoptosis-inducing activities in Jurkat $\mathrm{T}$ cells (Karg et al., 2007). One of the PhytoP, 16-epi$16-\mathrm{B}_{1}$-PhytoP, detected in the tissues of our study was reported to be neuroprotective in human neuroblastoma cells by reducing oxidative stress (Minghetti et al., 2014).

In in vivo, intake of ALA-rich flaxseed oil increased plasma and urine $\mathrm{F}_{1}$-PhytoP levels in healthy human. $\mathrm{F}_{1^{-}}$ PhytoP is proposed to be absorbed and circulated in plasma as conjugated form before being excreted as free acid (Barden et al., 2009; Karg et al., 2007). Of note, the increased ALA in the heart tissues of the HFD + Oat group may have contributed to the release of ent- $16-\mathrm{F}_{1 \mathrm{t}}-\mathrm{PhytoP}$, 16(RS)-13-epi-ST $\Delta^{14}-9-\mathrm{PhytoF}$, and 9-F $\mathrm{F}_{1}$-PhytoP. Such observation was not seen in the liver tissues. To date, limited reports have been available on the biological functions of PhytoP in in vivo. Insofar, only one in vitro study (Gutermuth et al., 2007) perceived that $16-\mathrm{F}_{1 \mathrm{t}^{-}}$ PhytoP can act like thromboxane $\mathrm{A}_{2}$ to trigger reversible platelet aggregation suggesting that $16-\mathrm{F}_{1 \mathrm{t}}-\mathrm{PhytoP}$ elevation in the HFD + Oat group may be beneficial to atherosclerosis.

Furthermore, our observation clearly showed liver and heart tissue levels of nonenzymatically mediated oxidized ADA products, namely $17-\mathrm{F}_{2 \mathrm{t}}$-dihomo-IsoP and 7- $\mathrm{F}_{2 \mathrm{t}}$-dihomo-IsoF to be induced in the HFD + Oat group compared to HFD. The role of dihomo-IsoP and dihomo-IsoF from ADA in atherosclerosis is not clear. Both products were identified in the heart tissue of Sprague Dawley rats where among the isofuranoids measured, 7- $\mathrm{F}_{2 \mathrm{t}}$-dihomo-IsoF was dominant (de la Torre et al., 2015).

Indeed, the poor response by the oat bran in regulating systemic cholesterol and triacylglycerol was unexpected. It may be due to an insufficient feeding time (16 vs 24 weeks) compared to other studies (Ryan et al., 2017). Also, other lipid species and pathways such as cholesterol metabolism that is related to the pathogenesis were not considered in our assessment. Other aspect that is worthy to consider in future study is the role of fiber and $\beta$-glucan in the oat bran that are claimed to improve the gut microbiome, which can indirectly improve atherosclerotic symptoms (Ryan et al., 2017).
In conclusion, this study for the first time elucidates the oxidized PUFA products in the liver and heart tissues of $A p o E^{-/-}$mice when fed with oat bran. Oat bran is claimed to be health performing through antioxidative and anti-inflammatory actions. Our observation failed to see these properties in atherosclerotic mice and instead it encouraged the elevation of proinflammatory and vasoconstricting oxidized products of $n-6$ PUFA with simultaneous reduction of anti-inflammatory oxidized products of $n-3$ PUFA. As a consequence, this may not be advantageous in the pathogenesis of atherosclerosis when observing PUFA-oxidative stress relationship in the metabolism.

Acknowledgement J.C.Y.L., D.S.A. K.P., and H.E.N. designed research (project conception, development of overall research plan, and study oversight); D.S.A., K.S.L., and J.C.Y.L. conducted research (hands-on conduct of the experiments and data collection); D.S.A. and J.C.Y.L. analyzed data or performed statistical analysis; C.O., J.M.G., and T.D. synthesized standards necessary for this research; H.E.N. and J.C.Y.L. wrote the article and have primary responsibility for the final content; All authors have read and approved the final manuscript. The authors would like to thank The University of Hong Kong, Small Grant Funding (201007176045) for the support of this project.

Conflict of Interest The authors declare that they have no conflict of interest.

\section{References}

Andersson, K. E., \& Hellstrand, P. (2012) Dietary oats and modulation of atherogenic pathways. Molecular Nutrition \& Food Research, 56:1003-1013. https://doi.org/10.1002/mnfr.201100706

Barden, A. E., Croft, K. D., Durand, T., Guy, A., Mueller, M. J., \& Mori, T. A. (2009) Flaxseed oil supplementation increases plasma F-1-phytoprostanes in healthy men. Journal of Nutrition, 139: 1890-1895. https://doi.org/10.3945/jn.109.108316

Burdge, G. C., \& Calder, P. C. (2005) Conversion of alpha-linolenic acid to longer-chain polyunsaturated fatty acids in human adults. Reproduction Nutrition Development, 45:581-597. https://doi. org/10.1051/rnd:2005047

Cracowski, J. L., \& Durand, T. (2006) Cardiovascular pharmacology and physiology of the isoprostanes. Fundamental \& Clinical Pharmacology, 20:417-427. https://doi.org/10.1111/j.1472-8206.2006. 00435. $\mathrm{x}$

Cuyamendous, C., de la Torre, A., Lee, Y. Y., Leung, K. S., Guy, A., Bultel-Ponce, V., ... Durand, T. (2016) The novelty of phytofurans, isofurans, dihomo-isofurans and neurofurans: Discovery, synthesis and potential application. Biochimie, 130:49-62. https://doi.org/10. 1016/j.biochi.2016.08.002

De Felice, C., Signorini, C., Durand, T., Oger, C., Guy, A., Bultel-Ponce, V., ... Hayek, J. (2011) F-2-dihomo-isoprostanes as potential early biomarkers of lipid oxidative damage in Rett syndrome. Journal of Lipid Research, 52:2287-2297. https://doi. org/10.1194/jlr.P017798

De la Torre, A., Lee, Y. Y., Mazzoni, A., Guy, A., Bultel-Poncé, V., ... Galano, J. M. (2015) Total syntheses and in vivo quantitation of novel neurofuran and dihomo-isofuran derived from 
docosahexaenoic acid and adrenic acid. Chemistry, 21:2442-2446. https://doi.org/10.1002/chem.201405497

Demion, M., Oger, C., Vigor, C., Thireau, J., Le Guennec, J. Y., Durand, T., ... Lee, J. C. Y. (2017) Two sides of the same coin: NEO-PUFAs in Rett syndrome and post-infarction cardiac arrhythmias. European Journal of Lipid Science and Technology, 119: 1600320. https://doi.org/10.1002/ejlt.201600320

Folch, J., Lees, M., \& Sloane Stanley, G. H. (1957) A simple method for the isolation and purification of total lipides from animal tissues. Journal of Biological Chemistry, 226:497-509.

Forman, B. M., Chen, J., \& Evans, R. M. (1997) Hypolipidemic drugs, polyunsaturated fatty acids, and eicosanoids are ligands for peroxisome proliferator-activated receptors alpha and delta. Proceedings of the National Academy of Sciences of the United States of America, 94:4312-4317.

Galano, J. M., Lee, Y. Y., Oger, C., Vigor, C., Vercauteren, J., Durand, T., ... Lee, J. C. Y. (2017) Isoprostanes, neuroprostanes and phytoprostanes: An overview of 25 years of research in chemistry and biology. Progress in Lipid Research, 68:83-108. https:// doi.org/10.1016/j.plipres.2017.09.004

Gladine, C., Newman, J. W., Durand, T., Pedersen, T. L., Galano, J. M., Demougeot, C., ... Comte, B. (2014) Lipid profiling following intake of the omega 3 fatty acid DHA identifies the peroxidized metabolites F-4-neuroprostanes as the best predictors of atherosclerosis prevention. PLoS One, 9:9, e89393. https://doi. org/10.1371/journal.pone.0089393

Gornas, P., Rudzinska, M., Raczyk, M., \& Soliven, A. (2016) Lipophilic bioactive compounds in the oils recovered from cereal by-products. Journal of the Science of Food and Agriculture, 96: 3256-3265. https://doi.org/10.1002/jsfa.7511

Goyens, P. L., Spiker, M. E., Zock, P. L., Katan, M. B., \& Mensink, R. P. (2006) Conversion of alpha-linolenic acid in humans is influenced by the absolute amounts of alpha-linolenic acid and linoleic acid in the diet and not by their ratio. American Journal of Clinical Nutrition, 84:44-53. https://doi.org/10.1093/ ajcn/84.1.44

Greaves, K., Dixon, S. R., Coker, I. O., Mallett, A., O’Neil, W. W., Senior, R., ... Marber, M. S. (2003) The influence of isoprostane F2alpha-III on reflow after myocardial infarction. European Heart Journal, 24:317-317. https://doi.org/10.1016/S0195-668x(03) 94822-6

Griendling, K. K., Sorescu, D., \& Ushio-Fukai, M. (2000) NAD(P)H oxidase: Role in cardiovascular biology and disease. Circulation Research, 86:494-501.

Gutermuth, J., Bewersdorff, M., Traidl-Hoffman, C., Ring, J., Mueller, M. J., ... Jakob, T. (2007) Immunomodulatory effects of aqueous birch pollen extracts and phytoprostanes on primary immune responses in vivo. Journal of Allergy and Clinical Immunology, 120:292-299.

Hwang, D. (2000) Fatty acids and immune responses-A new perspective in searching for clues to mechanism. Annual Review of Nutrition, 20:431-456. https://doi.org/10.1146/annurev.nutr.20. 1.431

Jahn, U., Galano, J. M., \& Durand, T. (2008) Beyond prostaglandins-Chemistry and biology of cyclic oxygenated metabolites formed by free-radical pathways from polyunsaturated fatty acids. Angewandte Chemie International Edition, 47: 5894-5955. https://doi.org/10.1002/anie.200705122

Jamieson, K. L., Endo, T., Darwesh, A. M., Samokhvalov, V., \& Seubert, J. M. (2017) Cytochrome P450-derived eicosanoids and heart function. Pharmacology \& Therapeutics, 179:47-83. https:// doi.org/10.1016/j.pharmthera.2017.05.005

Joumard-Cubizolles, L., Lee, J. C. Y., Vigor, C., Leung, H. H., Bertrand-Michel, J., Galano, J. M., ... Gladine, C. (2017) Insight into the contribution of isoprostanoids to the health effects of omega 3 PUFAs. Prostaglandins \& Other Lipid Mediators, 133: 111-122. https://doi.org/10.1016/j.prostaglandins.2017.05.005

Karg, K., Dirsch, V. M., Vollmar, A. M., Cracowski, J. L., Laporte, F., \& Mueller, M. J. (2007) Biologically active oxidized lipids (phytoprostanes) in the plant diet and parenteral lipid nutrition. Free Radical Research, 41:25-37. https://doi.org/10. 1080/10715760600939734

Kumar, A., Kingdon, E., \& Norman, J. (2005) The isoprostane 8-iso-PGF(2 alpha) suppresses monocyte adhesion to human microvascular endothelial cells via two independent mechanisms. FASEB Journal, 19:443-445. https://doi.org/10.1096/fj.04-1364fje

Lai, K. P., Lee, J. C. Y., Wan, H. T., Li, J. W., Wong, A. Y. M., Chan, T. F., ... Wong, C. K. C. (2017) Effects of in utero PFOS exposure on transcriptome, lipidome, and function of mouse testis. Environmental Science \& Technology, 51:8782-8794. https://doi. org/10.1021/acs.est.7b02102

Medina, S., De Miguel-Elizaga, I., Oger, C., Galano, J. M., Durand, T., Martinez-Villanueva, M., ... Gil-Izquierdo, A. (2015) Dihomo-isoprostanes-nonenzymatic metabolites of AdA-are higher in epileptic patients compared to healthy individuals by a new ultrahigh pressure liquid chromatography-triple quadrupole-tandem mass spectrometry method. Free Radical Biology and Medicine, 79:154-163. https://doi.org/10.1016/j.freeradbiomed.2014.11.005

Minghetti, L., Salvi, R., Lavinia Salvatori, M., Ajmone-Cat, M. A., De Nuccio, C., Visentin, S., ... Durand, T. (2014) Nonenzymatic oxygenated metabolites of alpha-linolenic acid B1- and L1-phytoprostanes protect immature neurons from oxidant injury and promote differentiation of oligodendrocyte progenitors through PPAR-gamma activation. Free Radical Biology \& Medicine, 73: 41-50. https://doi.org/10.1016/j.freeradbiomed.2014.04.025

Oliw, E. H., \& Sprecher, H. W. (1991) Metabolism of polyunsaturated $(n-3)$ fatty acids by monkey seminal vesicles: Isolation and biosynthesis of omega-3 epoxides. Biochimica et Biophysica Acta, 1086: 287-294.

Pan, A., Chen, M., Chowdhury, R., Wu, J. H. Y., Sun, Q., Campos, H., ... Hu, F. B. (2012) Alpha-linolenic acid and risk of cardiovascular disease: A systematic review and meta-analysis. American Journal of Clinical Nutrition, 96:1262-1273. https://doi. org/10.3945/ajcn.112.044040

Roy, J., Fauconnier, J., Oger, C., Farah, C., Angebault-Prouteau, C., Thireau, J., ... Le Guennec, J. Y. (2017a) Non-enzymatic oxidized metabolite of DHA, 4(RS)-4-F-4t-neuroprostane protects the heart against reperfusion injury. Free Radical Biology and Medicine, 102:229-239. https://doi.org/10.1016/j.freeradbiomed.2016.12.005

Roy, J., Galano, J. M., Durand, T., Le Guennec, J. Y., \& Lee, J. C. Y. (2017b) Physiological role of reactive oxygen species as promoters of natural defenses. FASEB Journal, 31:3729-3745. https://doi. org/10.1096/fj.201700170R

Roy, J., Oger, C., Thireau, J., Roussel, J., Mercier-Touzet, O., Faure, D., ... Le Guennec, J. Y. (2015) Nonenzymatic lipid mediators, neuroprostanes, exert the antiarrhythmic properties of docosahexaenoic acid. Free Radical Biology and Medicine, 86:269-278. https://doi.org/10.1016/j.freeradbiomed.2015.04.014

Ryan, P. M., Lis, L. E., Bjorndahl, T. C., Mandal, R., Murphy, K., ... Stanton, C. (2017) Microbiome and metabolome modifying effects of several cardiovascular disease interventions in apo- $\mathrm{E}^{-1-}$ mice. Microbiome, 5:30. https://doi.org/10.1186/s40168-017-0246-x.

Sacerdoti, D., Pesce, P., Di Pascoli, M., Brocco, S., Cecchetto, L., \& Bolognesi, M. (2015) Arachidonic acid metabolites and endothelial dysfunction of portal hypertension. Prostaglandins \& Other Lipid Mediators, 120:80-90. https://doi.org/10.1016/j.prostaglandins. 2015.05.008

Sapieha, P., Stahl, A., Chen, J., Seaward, M. R., Willett, K. L., ... Smith, L. E. (2011) 5-lipoxygenase metabolite 4-HDHA is a mediator of the antiangiogenic effect of omega-3 polyunsaturated fatty 
acids. Science Translational Medicine, 3:69ra12. https://doi.org/10. 1126/scitranslmed.3001571

Sasso, G. L., Schlage, W. K., Boué, S., Veljkovic, E., Paitsch, M. C., \& Hoeng, J. (2016) The Apoe ${ }^{-/-}$mouse model: A suitable model to study cardiovascular and respiratory diseases in the context of cigarette smoke exposure and harm reduction. Journal of Translational Medicine, 14:146.

Serhan, C. N., Chiang, N., \& Van Dyke, T. E. (2008) Resolving inflammation: Dual anti-inflammatory and pro-resolution lipid mediators. Nature Reviews. Immunology, 8:349-361. https://doi. org/10.1038/nri2294

Serhan, C. N., Dalli, J., Colas, R. A., Winkler, J. W., \& Chiang, N. (2015) Protectins and maresins: New pro-resolving families of mediators in acute inflammation and resolution bioactive metabolome. Biochimica et Biophysica Acta-Molecular and Cell Biology of Lipids, 1851:397-413. https://doi.org/10.1016/j.bbalip.2014. 08.006

Sethi, S., Eastman, A. Y., \& Eaton, J. W. (1996) Inhibition of phagocyte-endothelium interactions by oxidized fatty acids: A natural anti-inflammatory mechanism? Journal of Laboratory and Clinical Medicine, 128:27-38. https://doi.org/10.1016/S0022-2143(96) 90111-0

Smith, W. L., Garavito, R. M., \& DeWitt, D. L. (1996) Prostaglandin endoperoxide $\mathrm{H}$ synthases (cyclooxygenases)-1 and -2. The Journal of Biological Chemistry, 271:33157-33160.

Solberg, R., Longini, M., Proietti, F., Vezzosi, P., Saugstad, O. D., \& Buonocore, G. (2012) Resuscitation with supplementary oxygen induces oxidative injury in the cerebral cortex. Free Radical Biology \& Medicine, 53:1061-1067. https://doi.org/10.1016/j. freeradbiomed.2012.07.022

Van der Vusse, V. J., van Bilsen, M., \& Glatz, J. F. (2000) Cardiac fatty acid uptake and transport in health and disease. Cardiovascular Research, 45:279-293.
Vollmer-Conna, U., Cvejic, E., Smith, I. G., Hadzi-Pavlovic, D., \& Parker, G. (2015) Characterising acute coronary syndrome-associated depression: Let the data speak. Brain, Behavior, and Immunity, 48:19-28. https://doi.org/10.1016/j.bbi.2015. 03.001

Wan, J. B., Huang, L. L., Rong, R., Tan, R., Wang, J. D., \& Kang, J. X. (2010) Endogenously decreasing tissue n-6/n-3 fatty acid ratio reduces atherosclerotic lesions in apolipoprotein E-deficient mice by inhibiting systemic and vascular inflammation. Arteriosclerosis, Thrombosis, and Vascular Biology, 30: 2487-U2282. https://doi.org/10.1161/Atvbaha.110.210054

Weber, D. S., Rocic, P., Mellis, A. M., Laude, K., Lyle, A. N., Harrison, D. G., \& Griendling, K. K. (2005) Angiotensin II-induced hypertrophy is potentiated in mice overexpressing p22 (phox) in vascular smooth muscle. American Journal of Physiology-Heart and Circulatory Physiology, 288:H37-H42. https://doi.org/10.1152/ajpheart.00638.2004

Yura, T., Fukunaga, M., Khan, R., Nassar, G. N., Badr, K. F., \& Montero, A. (1999) Free-radical-generated F2-isoprostane stimulates cell proliferation and endothelin-1 expression on endothelial cells. Kidney International, 56:471-478. https://doi.org/10.1046/j. 1523-1755.1999.00596.x

Zafari, A. M., Ushio-Fukai, M., Akers, M., Yin, Q., Shah, A., Harrison, D. G., ... Griendling, K. K. (1998) Role of NADH/NADPH oxidase-derived $\mathrm{H} 2 \mathrm{O} 2$ in angiotensin II-induced vascular hypertrophy. Hypertension, 32:488-495.

Zeldin, D. C. (2001) Epoxygenase pathways of arachidonic acid metabolism. Journal of Biological Chemistry, 276:36059-36062. https://doi.org/10.1074/jbc.R100030200

Zu, L. Y., Guo, G., Zhou, B. D., \& Gao, W. (2016) Relationship between metabolites of arachidonic acid and prognosis in patients with acute coronary syndrome. Thrombosis Research, 144: 192-201. https://doi.org/10.1016/j.thromres.2016.06.031 